\title{
Liderlik Yönelimlerinin Çatışma Çözme Stratejileri Üzerindeki Etkisi (The Impact of Leadership Orientations on Conflict Resolution Strategies)
}

\section{Didem ÖZTÜRK ÇIFTCi iD a Hülya ERKANLI iD b}

a Ordu Üniversitesi, Fatsa Meslek Yüksek Okulu, Ordu, Türkiye. didemciftci@gmail.com

b Bolu Abant İzzet Baysal Üniversitesi, İktisadi ve İdari Bilimler Fakültesi, İşletme Bölümü erkanli h@ibu.edu.tr

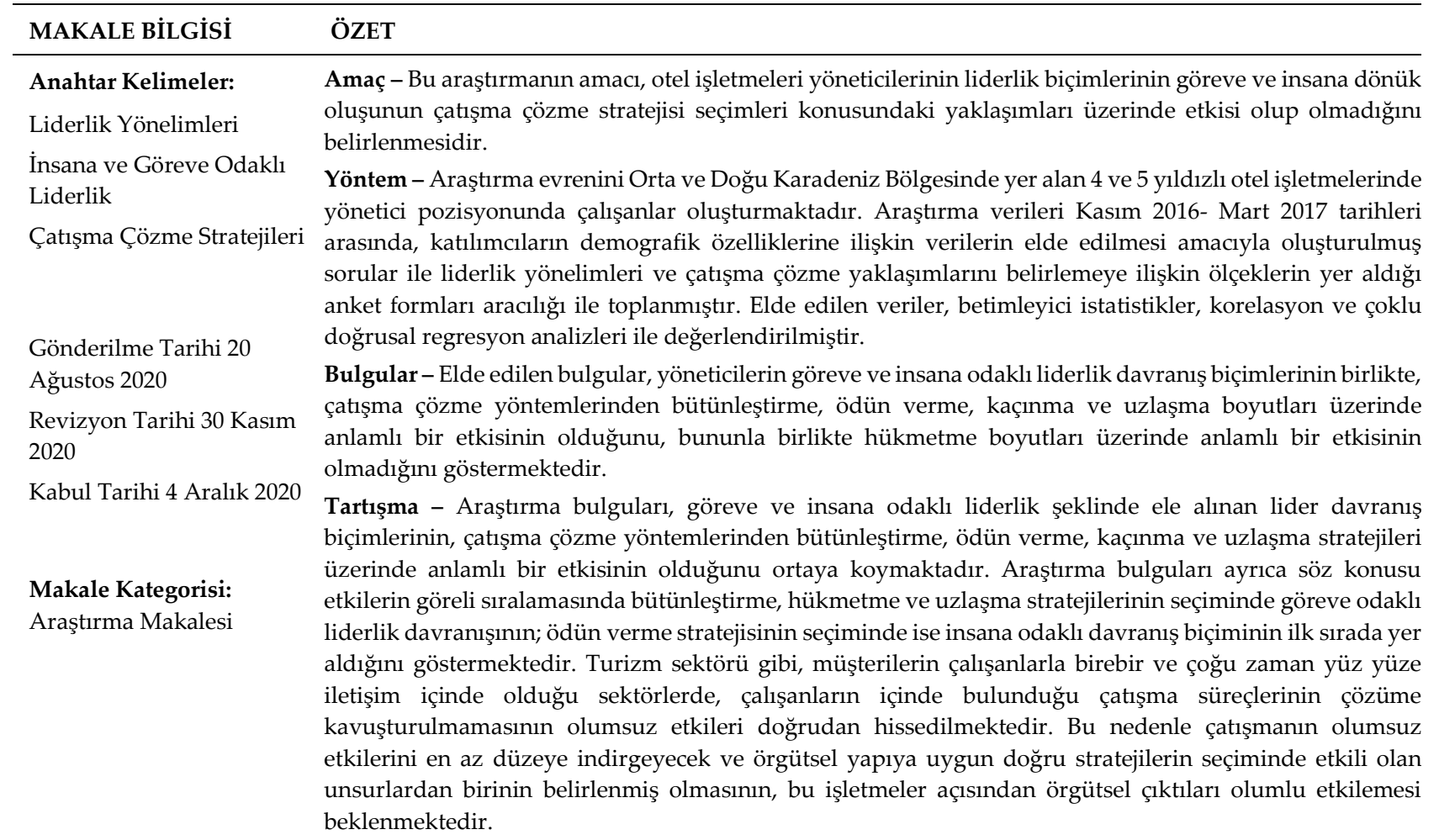

\section{ARTICLE INFO}

Keywords:

Leadership orientations

People and task oriented leadership

Conflict resolution strategies

Received 20 August 2020

Revised 30 November 2020

Accepted 4 December 2020

Article Classification:

Research Article

\section{ABSTRACT}

Purpose - The study aimed to determine whether the people-oriented leadership style or task-oriented leadership style of hotel managers have an impact on their approach to strategies to resolve conflict.

Design/methodology/approach - The study population consisted of hotel managers of four and five-star hotels in the Middle and Eastern Black Sea Regions in Turkey. Data were collected between November 2016 and March 2017 via questionnaires created to obtain data regarding demographic characteristics of the participants, and questionnaires that include scales for determining leadership orientations and strategies to resolve conflict. Data obtained were evaluated by using descriptive statistics, correlation, and multiple linear regression analyses.

Findings - The results showed that managers' adoption of task-oriented and people-oriented leadership styles together have a significant effect on the integration, compromise, avoidance, and reconciliation strategies among the methods of conflict resolution; however, that they did not have a significant effect on the domination strategy.

Discussion - The results of the study showed that task-oriented or people-oriented leadership styles have a significant effect on the integration, compromise, avoidance, and reconciliation strategies among methods of conflict resolution and in the relative ranking of these strategies. Task-oriented leadership style was in first place for integration, domination, and reconciliation strategies and people-oriented leadership style was in first place for compromise strategy. In sectors where customers are in direct communication and often face-to-face interaction with employees, such as tourism, the negative effects of not resolving a conflict by employees can be directly observed. Therefore, the authors consider that determining one of the factors that may minimize the negative effects of conflict and that is effective in choosing the right strategy for the organizational structure may have a positive effect on the organizational outcomes for such establishments. 


\section{GİRiş}

Çatışma kavramı, sosyal yaşamın bir parçası olduğu gibi, örgütsel yaşamın da kaçınılmaz bir gerçeğidir. Örgütlerde her ne kadar ortak amaçlar için bir araya gelmiş olsalar da farklı görev ve pozisyonlarda, farklı kişilik, deneyim ve eğitim gibi özellikleri olan birçok birey bir arada bulunmaktadır (Eren, 2011:585; Turkalj vd., 2008: 505). Sözü geçen farklılıklar doğru yönetilmediğinde, bu durum bireylerin istek ve ihtiyaçları arasında denge oluşturmayı zorlaştıracağı gibi örgütsel çatışmaların ortaya çıkmasına da neden olabilecektir. Bu nedenle, örgütsel anlamda çatışmaya işaret eden tüm ipuçlarının dikkatle takip edilmesi ve çatışmanın zamanında tespit edilerek başarılı şekilde yönetilmesi son derece önemlidir. Çatışmanın olumlu ve olumsuz etkilerine ve sonuçlarına odaklanan farklı bakış açılarına sahip araştırmalar olmakla birlikte, birleşilen ortak nokta çatışmaların başarılı yönetilmesinin örgütsel açıdan son derece önemli olduğudur. Tüm farklılıklara rağmen lider, insan ilişkilerini, insan faktörlerini anlama tekniklerini, iletişim süreçlerini, kişilerarası ve gruplar arası davranışı ve örgütsel dinamikleri kullanarak çatışmayı etkili bir şekilde yönetebilir (Limbare, 2012:172).

Otel işletmelerinde, yoğun ve standart olmayan çalışma saatleri, aşırı iş yükü, mevsimsel çalışma gibi olumsuzlukların müşteri ile bire bir iletişim halinde olan çalışanlar üzerinde baskı ve stres oluşturduğu yapılan araştırmalarla ortaya koyulmuştur (Hu ve Cheng, 2010; Tiyce vd., 2013; Aydın, 2004; Kocaman vd., 2012). Çalışanların üzerinde oluşan işe yönelik bu tür baskıların ise çatışmanın fitilini ateşleyecek unsurlardan biri olabileceği de bilinmektedir (Üngüren, 2009; Topaloğlu ve Boylu, 2006). Otel işletmelerinde çalışanların müşteri ile birebir iletişim içerisinde oluşu, çalışanlar arasında yaşanan çatışmaların yarattı̆̆ olumsuz etkilerin doğrudan müşteriye yansıyabileceği anlamına gelmektedir. Bu nedenle, çatışmaların doğru şekilde yönetilmesi ve sürecin mümkün olan en az hasarla hatta fırsata çevrilerek değerlendirilebilmesi ve bu bağlamda liderin sürece bakışı son derece önemlidir. Bu noktada liderin çatışmayı yönetme konusundaki yaklaşımının insana ya da göreve odaklanan bakış açısı ile çatışmanın örgüt içindeki gelişim sürecini değiştirebileceği ifade edilebilir.

$\mathrm{Bu}$ araştırmada, otel işletmeleri yöneticilerinin göreve ya da insana odaklı liderlik davranış biçimlerinin çatışma yönetim stratejilerine yönelik eğilimlerini etkileyip etkilemediğinin belirlenmesi amaçlanmıştır. Yapılan yazın taramasında özellikle liderin göreve ya da insana odaklı liderlik etme yaklaşımı ile çatışma çözüm stratejileri arasındaki ilişkiyi konu edinen az sayıda çalışma olduğu belirlenmiştir. Otelcilik sektörü müşteri beklentilerinin karşılanmasında çalışan davranışlarının önem taşıdığı bir sektördür. Bu bağlamda çatışma sürecinin başarılı şekilde yönetilmesi ile çalışan davranışları üzerinde oluşan olumlu etki müşteri beklentilerinin karşılanması dolayısıyla örgütsel çıktılara da katkı sağlayacaktır.

Araştırmada ilk olarak değişkenlere ilişkin kavramsal çerçeve oluşturulmuştur. Sonraki bölümde araştırma yöntemi ve hipotezlere yer verilmiştir. Araştırma hipotezlerine ilişkin analizler ve elde edilen değerler bulgular bölümünde; elde edilen sonuçlara ilişkin değerlendirme ise sonuçlar ve tartışma bölümünde ele alınmıştır.

\section{KAVRAMSAL ÇERÇEVE}

\subsection{Liderlik}

Liderlik, birçok yazar ve araştırmacı tarafından farklı şekillerde tanımlanmıştır. Örneğin, Donnelly, Gibson ve Ivancevich (1998: 336) liderliği, bir bireyin grubun diğer üyeleri üzerinde güç kullanarak onları belirli bir doğrultuda hareket etmeye teşvik etmesi şeklinde ifade ederken, Yukl (2006: 8) ise, başkalarını etkileme, neyin nasıl yapılması gerektiği konusunda fikir birliği oluşturma, belirlenen ortak hedeflere ulaşmak için bireysel ve toplu çabaları kolaylaştırma ve koordine etme süreci olarak tanımlamaktadır. Liderliğe ilişkin diğer bir tanımlama ise, kavramı izleyici odaklı değerlendiren Ribiere ve Sitar (2003) tarafından yapılmıştır. Yazarlar liderliğin, izleyicilerin belirlenmiş olan amaçların gerçekleştirilmesi noktasında katkı sağlayacak tüm yeteneklerini, gönüllülük ve örgütsel bağlılıklarını ortaya çıkarabilme süreci olduğunu belirtmişlerdir. Limbare (2012: 172), de benzer bakış açısıyla liderliğin iletişim sistemleri aracılığı ile belirli amaçlara ulaşmak için başkalarının çabalarını istenen doğrultuya yönlendirebilme, tutum ve davranışlarını şekillendirebilme yeteneği olduğunu ifade etmektedir. Yapılan tanımlardan da anlaşılabileceği gibi, liderliğin sadece liderin yapmış olduğu şeylerle ilgili olmadığı, izleyiciler olmadan liderlikten söz etmenin yetersiz olacağı 
söylenebilir. Bir başka ifadeyle, liderlik tüm etkileme, yönlendirme ve motive etme kavramlarıyla birlikte düşünülmeli, ancak tüm bu faktörlerin izleyicilerle birlikte anlam ifade ettiği unutulmamalıdır.

Liderlik konusunda çok farklı yaklaşımlar olmakla birlikte tarihsel gelişim süreci de dikkate alındığında bu yaklaşımlar; özellikler teorisi, davranışsal liderlik teorisi, durumsal liderlik teorisi ile liderlikte yeni yaklaşımlar şeklinde sınıflandırıldığ1 söylenebilir (Eren, 2011; Koçel, 2014; Tengilimoğlu vd., 2014). Bu araştırmada davranışsal liderlik yaklaşımları temelinde geliştirilmiş olan insana ve göreve odaklı liderlik tarzları konu edilmiştir.

Davranışsal Liderlik Yaklaşımı, lideri lider yapan unsurun kişisel özelliklerinden çok onun liderlik ederken sergilediği davranış biçimleri ve liderlik ettiği grubu oluşturan izleyicilerle olan ilişkileri olduğunu ileri sürmektedir (Koçel, 2014: 679). Bu yaklaşım kapsamında, Ohio State Üniversitesinin liderlik çalışmaları, Michigan Üniversitesi Enstitüsü Araştırmaları, Blake ve Mouton'un Yönetim Tarzı Matriksi ve Likert'in Sistem 4 yaklaşımı gibi çalışmalar yer almaktadır. Bu çalışmalardan, Ohio State Üniversitesi, Michigan Üniversitesi Enstitüsü Araştırmaları ile Blake ve Mouton'un Yönetim Tarzı Matriksi incelendiğinde liderliği iki temel davranışsal boyutta ele aldıkları görülmektedir (Gündüz Çekmecelioğlu, 2014: 23).

$\mathrm{Bu}$ boyutlar Ohio State Üniversitesinin çalışmaları sonucunda, işlerin ve amaçların gerçekleştirilmesine odaklanan ve çalışma ilişkilerini bu yönde düzenleyen liderleri tanımlayan "Yapıyı harekete geçirme" boyutu; diğeri ise iş ilişkilerinde karşılıklı güven, çalışanın fikir ve duygularına önem verilmesi şeklinde dostça bir yaklaşımı ifade eden "Anlayış" boyutu şeklinde ifade edilmiştir (Robbins ve Judge, 2017: 380). İlerleyen dönemde Michigan Üniversitesi'nde yapılan çalışmalarda ise aynı yaklaşımdan yola çıkarak "Göreve Odaklı Liderlik" ve "İnsana Odaklı Liderlik" boyutları tanımlanmıştır.

\subsection{1. İnsana Odaklı ve Göreve Odaklı Liderlik}

Insana Odaklı Liderlik; Çalışanlarını desteklemeye, geliştirmeye ve motive etmeye yönelik iş birliğini içeren olumlu ilişkiler ile sağlıklı iletişimi teşvik edici liderlik davranışları olarak tanımlanabilir (Rüzgar, 2018: 51). Çalışanlar ile olan ilişkileri ön planda tutan insan odaklı liderlerin, çalışanlarının hislerini dikkate aldıkları, ihtiyaçlarına yakın ilgi gösterdikleri ayrıca koordinasyonu sağlamak için takım ruhu oluşturma ve grup içerisinde güveni sağlamaya yönelik olumlu iletişim kanallarını kullanma şeklinde insanı ön plana alan davranış biçimlerini tercih ettikleri bilinmektedir (Taşkıran, 2006: 172; Özdevecioğlu ve Kanıgür, 2009: 55; Robbins ve Judge, 2017: 381). Eren (2011: 512), insana odaklı liderlerin, izleyicileri ile olan ilişkilerini haberleşme kanallarını açık tutarak, yetki ve sorumluluk devrederek ve astların kendi güçlerini kullanmasını destekleyerek oluşturduğunu; ayrıca karşılıklı güven, arkadaşlık ve duygusal anlamda destek sağlamaya yönelik davranışları ile bu ilişkileri güçlendirdiğini ifade etmektedir. Yukl vd. (2002: 19), ilişki odaklı liderlerin beş spesifik davranış biçimi olduğunu belirtmiştir. Yazara göre bu davranış biçimleri;

a) Destekleme; izleyicilerin duygu, düşünce ve ihtiyaçlarını dikkate alma ve ilgilenme,

b) Geliştirme; izleyicilere beceri, yetenek ve eğitim açısından kendilerini geliştirme fırsatları sağlama, bir problemin nasıl çözüleceğini açıklamak yerine bir görevi nasıl daha iyi gerçekleştireceğini öğrenmesine yardımcı olacak sorular sorma,

c) Tanıma; etkili performans ya da elde edilen başarıları takdir etme ve ödüllendirme,

d) Danışma; çalışanları karar mekanizmalarına dahil etme,

e) Güçlendirme; çalışanlara daha fazla yetki ve özerklik verme şeklinde sıralanmaktadır.

İnsana Odaklı Liderliğin Zayıf Yönleri; İnsana odaklı liderliğin eleştirilen yönleri içerisinde ilk sırayı, liderizleyici ilişkisinin bu denli yakınlaşmasının ast-üst ilişkisi açısından çizgileri bulanıklaştırabileceği görüşü almaktadır (Leonard, 2020). Ayrıca, çalışanlara çok fazla yetki ve sorumluluk devredilmesi halinde özellikle karar verme süreçlerinde yaşanması muhtemel problemlerin performansta ve müşteri memnuniyetinde düşüş ve buna bağlı olarak kârlılıkta azalma gibi olumsuz örgütsel ve mali sonuçlar doğurabileceği de yapılan eleştiriler arasında yer almaktadır (Rüzgar, 2018: 52). Bunun yanında insana çok fazla odaklana liderlik tarzının üretime yönelik gelişmeleri gözden kaçırabileceğine de dikkat çekilmektedir (Francis ve Milbourn, 1980; Aktaran, Özdevecioğlu, 2009: 55). 
İnsana Odaklı Liderliğin Güçlü Yönleri; İnsana odaklı liderlik tarzının destekleyici, güçlendirici yönetim anlayışı, çalışanların önemli ve değerli olduklarını hissetmelerini ve bunun sonucunda motivasyonun artmasını sağlamaktadır (Khuong ve Hoang, 20105: 211). Ayrıca insana odaklı davranış biçimlerinin çalışanın örgüte bağlllı̆̆ının artmasında ve böylece iş gören devir hızının azalmasında da olumlu etkisi söz konusudur (Koçel, 2014:680; Mathieu vd, 2016: 113). İnsana odaklı liderler, bir taraftan herkesin bir parçası olmak istediği takımlar yaratırken, diğer taraftan izleyicilerini her durumda destekleyen liderlik tarzlarıla onları risk alma ve üstesinden gelme konusunda cesaretlendirmekte ve tüm bunlar işyerinde verimliliği ve performansı arttırmaktadır (Rüzgar, 2018: 52; Özdevecioğlu ve Kanıgür, 2009: 79).

Göreve Odaklı Liderlik; Liderin belirlenen hedefleri gerçekleştirmek veya belirli bir performans standardına ulaşmak için tamamlanması gereken görevlere odaklandığı davranışsal bir yaklaşımdır (Rüzgar, 2018: 51). Göreve odaklı liderin, grup üyelerinin rollerini açıç̧a tanımlayarak organize ettiği ve her bir grup üyesinin hangi faaliyetleri ne zaman, nerede ve ne şekilde yapacağ (Waqar ve Siddiqui, 2008: 8). Göreve odaklı liderlik tarzında iş görenleri üretken olmaya zorlayarak sonuç elde etme eğiliminin yanında inisiyatif almaya odaklanarak tüm yönetsel süreçlerde kontrolü ellerinde bulundurma isteği de söz konusudur (Taşkıran, 2006: 171; Erol ve Koç, 2017: 569). Belirtilen noktalardan hareketle tipik bir görev odaklı liderin; çalışanları belirlediği işlerle görevlendirdiği, onlardan açıç̧a tanımlanmış performans düzeylerini yakalamalarını ve sürdürmelerini ve işlerin zamanında hatta belirtilen zamandan önce tamamlanmasını beklediği söylenebilir. Tüm bu beklentiler esnasında çalışanların içinde bulundukları herhangi bir durumdan daha çok sayılan hususların yerine getirilmesine odaklandığını söylemek de yanlış olmayacaktır (Robbins ve Judge, 2017: 380). Yukl (1971: 417), göreve odaklı liderlerin 3 karakterize davranış biçimi olduğunu ileri sürmektedir. Bunlar;

a) Verimlilik konusundaki endişelerini yansıtan performans arttırmaya yönelik ödül ve ceza davranışları,

b) Görevlere ilişkin kararların verilmesine yönelik davranışlar,

c) Alınan kararlar ve verilen direktiflerin yerine getirilmesini sağlamaya yönelik davranışlardır.

Göreve Odaklı Liderliğin Zayıf Yönleri; Bu tarzı benimseyen liderlerin görevlerin tamamlanması ve yüksek performans beklentisi ile izleyicilere uyguladığı baskının hem çalışanların kaygı, memnuniyetsizlik gibi olumsuz duygulara kapılmasına neden olduğu hem de yaratıcılıkları üzerinde olumsuz etki oluşturduğu ileri sürülmektedir (Casimir ve Keith Ng, 2010: 503; Rüzgar, 2018: 51). Wilkinson (2018: 39), çalışanları verimli ve verimli olmayan şeklinde kategorize eden görev odaklı yaklaşımın özellikle yaratıcılığı yüksek çalışanların demoralize olduklarını hissederek, kendilerini daha iyi ifade edebilecekleri başka örgütler aramalarına neden olabileceğini ifade etmektedir. Bir başka ifadeyle, görev odaklı liderlik davranışları, örgütlerde iş gören devir hızının artmasına yol açabilmektedir.

Göreve Odaklı Liderliğin Güçlü Yönleri; Bu liderlik tarzının en önemli avantajlarından biri, işlere ilişkin prosedür ve kuralların lider tarafından ayrıntılı şekilde oluşturulması ve uygulanmasına yönelik denetim mekanizmasının eksiksiz işlemesini sağlanmasıdır. Bu sistem, aynı zamanda işlerin zamanında ve mükemmel şekilde tamamlanmasını da sağlamaktadır (Rüzgar, 2018: 51). Bu liderlik biçiminde lider, çalışanlar için tüm işe yönelik mekanizmaları kullanıma hazır ve çalışanların yalnızca bu prosedürleri takip ederek işi tamamlayabileceği hale getirmekte ve bu şekilde çalışanlara rehberlik etmektedir (Khuong ve Hoang, 2015: 211). Bunların yanında, göreve odaklı liderler, mükemmel planlama ve organizasyon yetenekleri ile işletme kaynaklarının optimal kullanımını sağlamakta ve bu sayede verimliliği artırmaktadır (Standling, 2014).

\section{2. Örgütlerde Çatışma ve Yönetimi}

İnsanlar açısından çatışma gerek fizyolojik gerekse sosyo-psikolojik ihtiyaçların karşılanmasını engelleyecek herhangi bir olumsuzluğun getirdiği gerginlik durumu olarak tanımlanmaktadır (Eren, 2011: 585). Örgütsel anlamda çatışma ise, grubun bir veya daha fazla üyesinin inançlarına veya eylemlerine başka bir grubun bir veya daha fazla üyesi tarafından direnildiğinde, söz konusu gruplar ve grup üyeleri arasında ortaya çıkan anlaşmazlık durumu olarak ifade edilmektedir (Madalina, 2016: 808). Çatışma taraflardan birinin değer verdiği ya da olumlu değerlendirdiği bir olgunun diğer taraf tarafından olumsuz etkilendiği algısı ile başlayan bir süreçtir (Robbins ve Judge, 2017: 455). Çatışma tanımı çeşitli disiplinlerde farklılık gösterse de tanımların ortak noktası, farklı kişilik özellikleri, değerleri, ihtiyaçları ve arzuları olan kişiler ya da gruplar arasındaki etkileşim sonucu ortaya çıkmasıdır (Erzen ve Armağan, 2015: 225). Bununla birlikte çatışmaya neden 
olabilecek faktörler oldukça geniş bir yelpaze oluşturmaktadır. Çatışma, yaş, tecrübe, eğitim gibi demografik özellikler ya da tutum, davranış, değerler, kültür gibi sosyal ve psikolojik özelliklerin farklılaşmasından kaynaklanabileceği gibi, kıt kaynakların kullanımı, örgüt içindeki güç mücadelesi, örgütsel politikalardaki adaletsizlikler, yetersiz iletişim gibi örgütsel nedenlerden de kaynaklanabilmektedir. (Saeed vd, 2014: 216; Jokanović, vd. 2017: 448; Koçel, 2014: 770)

Örgütlerde çatışmanın nasıl karşılanacağına ilişkin gerek yazında gerekse uygulamada farklı görüşler bulunmaktadır. Geleneksel yaklaşım, çatışmayı olumsuz ve kaçınılması gereken bir olgu olarak görürken, ilişkisel görüş ise çatışmanın örgütsel etkinliği arttıracak pozitif bir kuvvet ve gerekli bir unsur olarak değerlendirilebileceğini ileri sürmektedir (Robbins ve Judge, 2017: 454; Turkalj vd., 2008: 507). Her iki görüşü de içeren yaklaşımda ise doğal olarak meydana gelen çatışmaların belirli bir düzeyde var olmasının örgütlerde yenilik, değişim ve yaratıcılık anlamında olumlu etki yaratabileceği, ancak sürekli ve çözümlenemeyen çatışmaların olduğu örgütlerde ise performansın olumsuz etkilenebileceği görüşü hakimdir (Koçel, 2014: 758).

\subsection{1. Çatışma Yönetimi ve Çözüm Yaklaşımları}

Örgütlerin başarısı, ortaya çıkması kaçınılmaz olan çatışma sürecinin tespiti ve başarılı şekilde yönetilmesi ile yakından ilişkilidir. Çatışma yönetimi, çatışmayı bir engel olarak görmek yerine faydalı yönlerini ortaya çıkarmayı amaçlayan yaklaşım ve uygulamalardır (Tengilimoğlu vd., 2014: 317). Bir başka ifadeyle çatışmayı yapıcı şekilde ele alarak, örgütsel yararlar doğrultusunda yaratıcı bir biçime dönüştürebilmek, bu olguyu başarılı şekilde yönetmek olarak değerlendirilebilir (Bumin, 1990: 9). Çatışmanın doğru yönetimi, potansiyel olumsuz etkilerinden örgütü korumanın yanında, olumlu etkilerinin ortaya çıkması ve değerlendirilmesini de sağlayabilir (Erzen ve Armağan, 2015: 226). Bu bağlamda çatışmanın yönetimi, her zaman çatışmanın çözüme kavuşturulması ya da ortadan kaldırılması şeklinde gerçekleşmeyebilir (Jokanović, vd., 2017: 448). Aksine işletme yönetimi çatışmanın işlevsel olabileceği düşüncesinde ise bu durumda çatışma ortamını teşvik edici bir yaklaşım sergilemekte ve optimal düzeyde çatışmayı kontrol dışına çıkmayacak şekilde teşvik edecek stratejileri uygulama yoluna gitmektedir. Örgüt içinde çatışma yönetimine ilişkin diğer yaklaşım ise çatışmayı çözmeye ve ortadan kaldırmaya yönelik stratejileri içermektedir. Çatışmayı çözme odaklı bir yaklaşım sergilemeyi hedefleyen işletme yönetimleri bunu çok farklı yöntemler ile gerçekleştirebilirler. Bu bağlamda yöneticilerin çatışmayı çözmeye yönelik izleyebilecekleri stratejilerden bazıları şunlardır (Robbins ve Judge, 2017; Koçel, 2014). Yaygın olarak kabul gören ve bu araştırmada da esas alınan çatışma çözme yaklaşımlarından birisi de Rahim (1983) tarafından geliştirilmiştir. Bu yaklaşıma ait çözüm stratejileri aşağıda kısaca açılanmıştır (Rahim vd., 1999; Rahim ve Katz, 2020);

Bütünleştirme; Çatışmanın, çözüme ulaştırılması amacıyla tarafların bir araya getirilerek çatışmanın nedenlerini ortaya koymaları ve değerlendirmelerine olanak sağlayacak şekilde yönetilmesidir. Tarafların tümünün çözümde aktif olarak yer alması muhtemel endişeleri azaltmanın bir yolu olarak düşünülebilir (Sportsman ve Hamilton, 2007: 158). Bu çözüm yaklaşımının, özellikle çatışmaya neden olan konunun karmaşık ve ancak farklı bakış açılarının katılımı ile çözülebileceği, tarafların katılıma istekli olduğu ayrıca çözüm için zaman sınırlamasının olmadığı durumlarda kullanılması uygundur (Tuna ve Türkmen, 2015: 48). Yine, bu tarz bir çözüm yaklaşımının, hatalı ya da eksik iletişim nedeniyle ortaya çıan çatışmaların çözümünde de etkili olduğu söylenebilir (Gürer vd., 2014: 444).

Ödün Verme; Çatışmanın çözüme kavuşturulması amacıyla, taraflardan birinin karşı tarafın endişelerini giderebilmek için kendi istek ve ihtiyaçlarını göz ardı etmesi, buna karşılık diğer tarafın istek ve ihtiyaçlarının ön plana çıkmasını kabullenmesi şeklinde gerçekleşen yaklaşımdır. Bu yaklaşımın temelinde fedakârlık, yardım ve itaat yer almaktadır (Arslan, 2016: 45; Koçak ve Atanur Başkan, 2013: 213). Bir başka ifadeyle, taraflardan biri çatışma nedenleri arasında yer alan istek ya da tutumlarından ödün vermekte ve çatışmayı sona erdirmek için fedakârlık yapmayı kabul etmektedir. Bu çatışma çözme yaklaşımı, yalnızca bir tarafın beklentilerinin karşılanması ile sonuçlandığından zayıf bir çözüm şekli olarak görülmektedir (Gürer vd., 2014: 444). Bununla birlikte, özellikle taraflardan birinin hatalı olduğunu düşündüğü ve kabul ettiği, taraflar arasında statü ve konum farklılıklarının belirgin olduğu veya ilişkilerin devamının önemli olduğu durumlarda kullanılabileceği ifade edilebilir (Tuna ve Türkmen, 2015: 48).

Kaçınma; Çatışmaya herhangi bir müdahale gerçekleştirmeden hatta görmezden gelme şeklinde gerçekleşen davranış biçimidir. Ancak yöneticilerin sorunla yüzleşmekten kaçınma eğilimi sonucunda, görmezden gelindiği için çözülemeyen ihtilafların ilerleyen dönemlerde daha büyük sorunlara neden olacak şekilde geri 
gelebileceği düşünüldüğünde daha çok kısa vadeli bir geçiştirmeden ibaret olabileceği söylenebilir (Arslan, 2016: 45; Koçak ve Atanur Başkan, 2013: 213). Bununla birlikte, çok büyük ve önemli olmayan çatışmalarda, tarafların yüzleşmesinin yaratacağı olumsuz etkinin çatışmanın çözülmesi durumunda sağlanacak faydadan fazla olması durumunda ya da karmaşık bir sorunun ele alınması için gereken sakinleşme süresini elde etmek amacıyla kullanılabilir (Rahim, 2002: 220).

Uzlaşma; Her iki tarafın da karşılıklı olarak kabul edilebilir bir çözüme ulaşmak amacıyla birtakım şeylerden vazgeçtiği “Ver ve al” şeklinde de ifade edilebilecek çözüm yaklaşımdır (Rahim, 2002: 220). Bir başka ifadeyle, bu çözüm yaklaşımında taraflardan hiçbiri kesin kazanan ya da kesin kaybeden değildir. Bu durum, taraflar arasında düşmanca tavırların ortaya çıkmasını engellediği için çatışma için geliştirilen çözümün kalıcı olmasına da katkı sağlaması beklenebilir. Bu tarzın uygulanabilmesi için tarafların kendi fikirleri, istekleri ve doğruları kadar, karşı tarafınkileri de dikkate alabilmesi ve hak verebilmesi gerekmektedir (Ayan ve Yavuz, 2018: 749). Bu yöntemin, tarafların güçlerinin eşit ve amaçlarının önemli olduğu durumlarda ve uzun süreli çatışmanın engellenmesi amacıyla kullanılması uygundur (Tuna ve Türkmen, 2015: 48; Rahim, 2002: 220).

Hükmetme; Çatışmaya neden olan konunun ele alınıp değerlendirilmesi yerine bir tarafın sahip olduğu gücü kullanıp diğer tarafa baskı uygulayarak kendisi için olumlu sonuçlar elde etmesi, buna karşılık çatışmanın diğer tarafının tamamen kaybeden olmasına neden olduğu yaklaşımdır (Chen vd., 2019: 460; Arslan, 2016: 44). Bu çözüm yaklaşımının, acil çözülmesi gereken nispeten önemsiz çatışmalar söz konusu olduğunda, tarafların kabul edilebilir bir noktada birleşmesinin mümkün olmadığı ve astların karar alma noktasında yeterli tecrübe ve donanıma sahip olmadığı durumlarda kullanılması tercih edilebilir (Rahim, 2002: 220).

\section{YÖNTEM}

\subsection{Hipotezlerin Oluşturulması}

Liderlik yönelimleri, örgütlerde çatışma yönetiminin hangi strateji ve uygulamalar ile gerçekleştirileceğini belirleyen en önemli faktörlerden birisidir (Erzen ve Armağan, 2015: 232). Bir başka ifadeyle, liderler sergiledikleri liderlik tarzları aracılığıyla çatışma yönetiminin de tarzını belirlemektedir (Chandolia ve Anastasiou, 2020: 457). Bu durum, farklı liderlik tarzlarını örgütte farklı iletişim ve karar verme biçimleri oluşturması ile açıklanabilir (Richmond vd., 1983: 28). Ayrıca yapılan araştırmalar, söz konusu yaklaşımı destekleyecek şekilde liderin, ortaya koyduğu davranış biçimleri ile çatışma sürecinin seyrini ve tarafları etkilediğini ortaya koymaktadır (Hendel vd., 2005: 138; Saeed vd., 2014: 222). Bu noktadan hareketle, liderin insana ya da göreve odaklı davranış yönelimlerinin, çatışma durumuna bakış açılarını ve çözüm stratejilerine yaklaşımlarını etkilemesi beklenebilir.

Araştırma değişkenlerine ilişkin kavramsal çerçeve ve tasarlanan araştırma modeli bağlamında hipotezler aşağıda yer aldığı şekli ile oluşturulmuştur;

H1: İnsana ve göreve odaklı liderlik yaklaşımları, çatışma çözmede bütünleştirme stratejisini etkilemektedir. H2: İnsana ve göreve odaklı liderlik yaklaşımları, çatışma çözmede ödün verme stratejisini etkilemektedir. H3: İnsana ve göreve odaklı liderlik yaklaşımları, çatışma çözmede kaçınma stratejisini etkilemektedir.

H4: İnsana ve göreve odaklı liderlik yaklaşımları, çatışma çözmede uzlaşma stratejisini etkilemektedir. H5: İnsana ve göreve odaklı liderlik yaklaşımları, çatışma çözmede hükmetme stratejisini etkilemektedir.

\subsection{Araştırma Modeli}

Birden fazla özellik arasındaki ilişkinin toplanan veriler aracılığı ile sorgulandığı ilişkisel tarama modeli (Can, 2017:9) temelinde oluşturulan bu araştırma, liderlerin göreve ya da insana odaklı davranış biçimlerinin çatışma çözme yöntemleri alt boyutları üzerindeki etkisini ve etkinin varlığının doğrulanması durumunda düzeyini belirlemeye yönelik olarak tasarlanmışır. Araştırmanın bağımsız değişkeni liderlerin göreve ve insana odaklı liderlik davranış biçimleri, bağımlı değişkeni ise çatışma çözme yöntemleri olan "Bütünleştirme, ödün verme, kaçınma, uzlaşma ve hükmetme" alt boyutları olarak belirlenmiştir.

\subsection{Araştırmanın Amacı ve Önemi}

$\mathrm{Bu}$ araştırmanın amacı, liderlerin göreve ya da insan odaklı davranış biçimlerinin çatışmayı çözme konusundaki yaklaşımları üzerinde etkili olduğu varsayımını sınamaktır. Yapılan yazın taramasında söz konusu değişkenler ile otel yöneticileri örnekleminde gerçekleştirilirmiş bir araştırmaya rastlanmamıştır. Bu açıdan araştırmanın, yazına katkı sağlayacağı düşünülmektedir. Konaklama sektöründe, müşteri ile çalışan 
arasında bire bir etkileşimin söz konusu olduğu ve çalışanların duygu, düşünce ve davranışlarının bu etkileşimin bir parçası olduğu bilinmektedir. Bu açıdan bakıldığında, çalışanların dâhil olduğu herhangi bir örgütsel çatışmanın başarılı şekilde yönetilememesi durumunda, çalışanların söz konusu çatışmanın oluşturduğu gerilimin etkisi ile olumsuz bakış açılarını müşterilere yansıtması da mümkün görülmektedir. Bu nedenle özellikle müşteri ile etkileşimin bu denli önemli olduğu hizmet sektöründe örgütsel çatışmaların doğru ve başarılı yönetilmesinin önemli olduğu ifade edilebilir. Bu bağlamda, araştırma sonuçlarının bu açıdan otel sektöründe çalışmakta olan yöneticilerin çalışanlara yaklaşımının çatışmayı başarılı şekilde yönetmede etkisi olup olmadığı konusunda aydınlatıcı olması beklenmektedir.

\subsection{Araştırma Evreni ve Örneklem}

Araştırma evreni Orta ve Doğu Karadeniz Bölgesinde yer alan 4 ve 5 yıldızlı otel işletmelerinde yönetici pozisyonunda çalışanlardan oluşmaktadır. Araştırma verileri Kasım 2016- Mart 2017 tarihleri arasında örneklem çerçevesinde yer alan oteller ziyaret edilerek, ya da telefonla iletişim kurularak toplanmıştır. Veri toplama aşamasında söz konusu bölgede 31 adet 4 ve 5 yıldızlı otel işletmesinin faaliyet gösterdiği tespit edilmiştir. Bu otellerde yönetici pozisyonunda görev yapan 132 yönetici, araştırma evrenini oluşturmaktadır. Söz konusu otellerden 7 tanesinin yöneticileri araştırmaya katılmayı kabul etmemiş, katılımı kabul eden 24 otelin yöneticileri örneklem çerçevesini oluşturmuştur. Veri toplamak amaciyla yöneticilere teslim edilen 115 anket formundan 98 adet geri dönüş sağlanmıştır. Dönüş sağlanan formların 9 tanesi eksik ya da hatalı doldurulduğundan değerlendirmeye alınmamıştır. Sonuç olarak 89 adet formun içerdiği veriler, istatistiksel analizlerde kullanılacak veri setini oluşturmak üzere araştırmaya dâhil edilmiştir. Araştırma evreni için gerekli örneklem sayısı 86 olarak hesaplandığından ( $\mathrm{p}=0.8 ; \mathrm{q}: 0.2 ; \mathrm{t}=1.96)$, veri setinin yeterli olduğu ifade edilebilir.

\subsection{Veri Toplama Araçları}

Araştırma verileri, üç bölümden oluşan bir anket formu aracılığıyla toplanmıştır. Anket formunun ilk bölümünde katılımcıların demografik özelliklerine ilişkin verilerin elde edilmesi amacıyla oluşturulmuş sorular yer almaktadır. Formun ikinci bölümünde liderlik yönelimleri, üçüncü bölümünde ise çatışma çözme yaklaşımlarını belirlemeye ilişkin ölçekler yer almaktadır.

Liderlik Yönelimleri Ölçeği; Araştırmada, yöneticilerin liderlik yönelimleri “Göreve" ve "İnsana” odaklı liderlik şeklinde ele alınan yaklaşım ile değerlendirilmiştir. Bu yaklaşım çerçevesinde liderlik yönelimlerini ölçmek amacıyla Luthans (1992) tarafından geliştirilen "Liderlik Yönelimleri Ölçeği” kullanılmıştır. Ölçeğin uyarlaması ve geçerlik güvenirlik çalışması Cömert (1999) tarafından yapılmış ve sonrasında birçok araştırmada kullanılmıştır. Ölçek 35 ifadeden oluşmaktadır. Puanların hesaplanmasında "her zaman" ile "sık sık" ve "çok nadir" ile "hiçbir zaman" cevapları değerlendirmeye alınmıştır. "Her zaman" ile "sık sık" cevapları pozitif, "çok nadir" ve "hiçbir zaman" cevapları ise negatif bir eğilime işaret etmektedir. "Ara sıra" cevabını işaretleyen katılımcının ise ifadeye ilişkin puanı sıfır olarak kabul edilmektedir. Ölçek değerlendirilirken, 8,12,17,18,19,30, 34 ve 35 numaralı ifadeler için "çok nadir" ve "hiçbir zaman" işaretlenirse, bu ifadelerin önüne 1 yazılır. Kalan diğer ifadeler için ise "her zaman" ve "sık sık" işaretlenirse, bu ifadelerin önüne de 1 yazılır. Daha sonra 3,5,8,10,15,18,19,22,24,26,28,30,32,34 ve 35 numaralı ifadeler için işaretlenen 1'ler toplanarak "insana yönelik" puan, kalan 1'lerin toplanması ile de "göreve yönelik" puan elde edilir.

Çatışma Yönetimi Stratejileri Ölçeği (ROCI-II); Araştırmada, yöneticilerin çatışmayı çözme noktasındaki stratejilerini belirlemek amacıyla, Rahim (1983) tarafından geliştirilen ve Yağcıŏlu (1997) tarafından uyarlaması ve geçerlik güvenirlik çalışması yapılan "Çatışma Yönetim Stratejileri Ölçeği (ROCI-II)" kullanılmıştır. Ölçek, 28 ifade ve "Bütünleştirme, Ödün Verme, Kaçınma, Uzlaşma, Hükmetme" şeklinde beş alt boyuttan oluşmaktadır. Ölçek beşli likert şeklinde tasarlanmıştır. Ölçekte; 1., 4., 5., 12., 22., 23. ve 28. maddeler bütünleştirme, 2., 10., 11., 13., 19. ve 24. maddeler ödün verme; 8., 9., 18., 21. ve 25. maddeler hükmetme; 3., 6., 16., 17., 26. ve 27. maddeler kaçınma ve 7., 14., 15. ve 20. maddeler de uzlaşma stratejilerine yönelik ifadeleri içermektedir.

\subsection{Veri Analizinde Kullanılan İstatistiksel Yöntemler}

Araştırma verileri, araştırma problemini test etmek amacıyla SPSS paket programı kullanılarak çoklu doğrusal regresyon yöntemi ile değerlendirilmiştir. Ayrıca, demografik değişkenlere ilişkin tanımlayıcı istatistikler, 


\section{D. Öztürk Çiftci - H. Erkanlı 12/4 (2020) 3930-3946}

ölçek güvenilirliklerinin belirlenmesinde Cronbach's Alpha katsayısı, verilerin normal dağılıp dağılmadığını belirlemek amacıyla çarpıklık ve basıklık değerleri ve değişkenler arası ilişkilerin belirlenmesinde de korelasyon analizi yine aynı program aracılığı ile tespit edilmiştir.

\section{BULGULAR}

\section{1. Örneklem Grubuna İlişkin Demografik Bulgular}

Tablo 1: Örneklem Grubuna İlişkin Demografik Bilgiler

\begin{tabular}{|c|c|c|c|}
\hline & & Frekans & Yüzde (\%) \\
\hline \multirow{3}{*}{ Cinsiyet } & Kadin & 34 & 31,2 \\
\hline & Erkek & 55 & 61,8 \\
\hline & Toplam & 89 & 100 \\
\hline \multirow{6}{*}{ Yaş } & 25 yas ve altı & 4 & 4,5 \\
\hline & $26-35$ yaș arası & 46 & 51,7 \\
\hline & $36-45$ yas arası & 25 & 28,1 \\
\hline & $46-55$ yaș arası & 10 & 11,2 \\
\hline & 55 vas ve üstü & 4 & 4,5 \\
\hline & Toplam & 89 & 100 \\
\hline \multirow{6}{*}{ Eğitim Düzeyi } & İlköğretim & 2 & 2,2 \\
\hline & Lise & 23 & 25,8 \\
\hline & Ön Lisans & 18 & 20,2 \\
\hline & Lisans & 39 & 43,8 \\
\hline & Lisansüstü & 7 & 7,9 \\
\hline & Toplam & 89 & 100 \\
\hline \multirow{4}{*}{ Toplam Çalışma Süresi } & 4 yıl ve daha az & 29 & 32,6 \\
\hline & 5-7 yıl arası & 19 & 21,3 \\
\hline & 8 y1l ve daha fazla & 41 & 46,1 \\
\hline & Toplam & 89 & 100 \\
\hline \multirow{3}{*}{ Turizm Eğitimi } & Aldım & 41 & 46,1 \\
\hline & Almadım & 48 & 53,9 \\
\hline & Toplam & 89 & 100 \\
\hline \multirow{10}{*}{ Pozisyon } & Genel Md. ve Genel & 15 & 16,8 \\
\hline & İnsan Kaynakları Müdürü & 5 & 5,6 \\
\hline & Mali İşler Müdürü & 8 & 9 \\
\hline & Ön Büro Müdürü & 19 & 21,3 \\
\hline & Housekeeping Müdürü & 7 & 7,9 \\
\hline & Teknik Müdür & 4 & 4,5 \\
\hline & Satış Pazarlama Müdürü & 6 & 6,7 \\
\hline & Yiyecek-İçecek Müdürü & 12 & 13,5 \\
\hline & Diğer & 13 & 14,5 \\
\hline & Toplam & 89 & 100 \\
\hline
\end{tabular}

Tablo 1'de yer alan bulgular incelendiğinde, katılımcıların \%31,2'sinin kadın, \%61,8'inin ise erkek olduğu ve $\% 51,7$ ile büyük bölümünün 26-35 yaş aralığında yer aldığı görülmektedir. Katılımcıların eğitim durumları incelendiğinde ise toplamda \%71,9'unun bir üniversite derecesine sahip olduğu görülmektedir. Ayrıca araştırmaya katılan otel yöneticilerinin \%53,9'unun turizm eğitimi almadığ uzun süre çalışma tecrübesine sahip olduğu da Tablo 1'de görülmektedir. Yine katılımcıların yönetim kademesindeki görevleri ön büro müdürü $(\% 21,3)$, genel müdür ve yardımcısı $(\% 16,8)$, yiyecek içecek müdürü (\%13,5), şeklinde sıralanmaktadır.

\subsection{Normal Dağılıma İlişkin Bulgular}

Verilerin analizinde hangi yöntemlerin kullanılacağının belirlenmesi amacıyla öncelikle verilerin normal dağılım gösterip göstermedikleri incelenmiştir. Bu amaçla çarpıklık ve basıklık değerleri incelenmiş ve bulgular Tablo 2' de gösterilmiştir. 
D. Öztürk Çiftci - H. Erkanlı 12/4 (2020) 3930-3946

Tablo 2: Değişkenlere İlişkin Çarpıklık ve Basıklık Değerleri

\begin{tabular}{l|c|c}
\hline Değişkenler & Çarpıklık & Basıklık \\
\hline Göreve Odaklı Liderlik & $-1,215$ & 1,615 \\
İnsana Odaklı Liderlik &,- 236 &,- 563 \\
\hline Bütünleştirme &,- 674 &, 818 \\
Ödün Verme &,- 050 &, 126 \\
Hükmetme &, 284 &,- 678 \\
Kaçınma &, 010 &,- 256 \\
Uzlaşma &,- 368 &, 607 \\
\hline
\end{tabular}

Çarpıklık ve basıklık değerlerinin +2;-2 aralığında yer alması normal dağılıma işaret etmektedir (Tabachnick ve Fidell, 2013; Can, 2017). Tablo 2'de yer alan değerler incelendiğinde değişkenlere ilişkin çarpıklık ve basıklık değerlerinin söz konuş aralıkta yer aldığı görülmektedir. Buna bağlı olarak verilerin normal dağılım gösterdiği ifade edilebilir.

\section{3. Ölçek Güvenilirlik Değerleri}

Gerek yurtdışı gerekse ülkemize akademik araştırmalarda birçok kez kullanılarak yapısal geçerlilikleri doğrulanmış olan liderlik yönelimleri ve çatışma çözme stratejileri ölçeklerinin iç tutarlılık güvenilirliklerini belirlemek amacıyla olan Cronbach's Alpha istatistiği kullanılmıştır. Tablo 3 ve Tablo 4'de ölçeklere ilişkin Cronbach's Alpha katsayıları görülmektedir.

Tablo 3: Liderlik Yönelimleri Ölçeği Güvenilirlik Düzeyi

\begin{tabular}{l|c|c}
\hline & Cronbach's Alpha & İfade Sayısı \\
\hline İnsana Odaklı Liderlik & 0,731 & 15 \\
Göreve Odaklı Liderlik & 0,861 & 20 \\
\hline
\end{tabular}

Tablo 4: Çatışma Çözme Stratejileri Ölçeği Güvenilirlik Düzeyi

\begin{tabular}{l|c|c}
\hline & Cronbach's Alpha & İfade Sayısı \\
\hline Bütünleştirme & 0,852 & 7 \\
Ödün verme & 0,697 & 6 \\
Hükmetme & 0,677 & 5 \\
Kaçınma & 0,704 & 6 \\
Uzlaşma & 0,671 & 4 \\
\hline
\end{tabular}

Cranbach's Alpha katsayısı 0 ile 1 arasında değerler almaktadır. Bu katsayı 1'e yaklaştıkça güvenilirliğin arttığı ve genelde 0,60'ın üzerindeki değerlerin oldukça güvenilir olduğu kabul edilmektedir (Tavşancıl, 2006; Aktaran, Can, 2017). Tablo 3 ve 4 'de görüldüğü gibi araştırma ölçeklerinin araştırmada kullanıldığı şekli ile alt boyutlarının güvenilirlik düzeyi oldukça yüksektir.

\subsection{Değişkenlere İlişkin Korelasyon Analizleri}

Araştırmanın bu bölümünde insana ve göreve odaklı liderlik davranış biçimleri ile çatışma çözme stratejileri olan bütünleştirme, ödün verme, hükmetme, kaçınma ve uzlaşma arasındaki ilişkiler 0,01 ve 0,05 anlamlılık düzeylerinde incelenmiştir. Değişkenler arası ilişkileri ifade eden korelasyon analizi değerleri ile yine araştırma değişkenlerine ait ortalama ve standart sapma değerleri de Tablo 5'de yer almaktadır. 
D. Öztürk Çiftci - H. Erkanlı 12/4 (2020) 3930-3946

Tablo 5: Değişkenlere İlişkin Korelasyon Analizleri

\begin{tabular}{|c|c|c|c|c|c|c|c|}
\hline Değişkenler & $\begin{array}{l}\text { İnsana } \\
\text { Odakl1 }\end{array}$ & $\begin{array}{l}\text { Göreve } \\
\text { Odaklı }\end{array}$ & Bütünleştirme & $\begin{array}{l}\text { Ödün } \\
\text { Verme }\end{array}$ & Hükmetme & Kaçınma & Uzlaşma \\
\hline İnsana Odaklı & 1 & & & & & & \\
\hline Göreve Odaklı &, $556^{*}$ & 1 & & & & & \\
\hline Bütünleştirme &, $383^{* *}$ &, $452^{* *}$ & 1 & & & & \\
\hline Ödün Verme &, $385^{* *}$ &, $366^{*}$ & $643^{* *}$ & 1 & & & \\
\hline Hükmetme & ,078 & $281^{* *}$ & $260^{*}$ & $396^{* *}$ & 1 & & \\
\hline Kaçınma & ,008 & 192 &, $214^{*}$ & $481^{* *}$ &, $572^{* *}$ & 1 & \\
\hline Uzlaşma &, $267^{*}$ &, $385^{* *}$ &, $737^{* *}$ &, $707^{* *}$ & $406^{* *}$ &, $359^{* *}$ & 1 \\
\hline Ortalama & 7,05 & 14,03 & 4,10 & 3,42 & 3,05 & 2,88 & 3,85 \\
\hline SS & 2,710 & 3,584 & 0,636 & 0,591 & 0,759 & 0,731 & 0,666 \\
\hline
\end{tabular}

** $\mathrm{p}<0,01 ;{ }^{*} \mathrm{p}<0,05 / \mathrm{N}=89$

Tablo 5 incelendiğinde, insana odaklı liderlik ile bütünleştirme, ödün verme ve uzlaşma stratejileri arasında istatistiksel olarak anlamlı ilişki olduğu, bunun yanında hükmetme ve kaçınma stratejileri arasında ise anlamlı bir ilişki bulunmadığı görülmektedir. Yine Tablo 5 'de göreve odaklı liderlik ile bütünleştirme, ödün verme, hükmetme ve uzlaşma stratejileri arasında istatistiksel olarak anlamlı bir ilişki söz konusu iken kaçınma stratejisi ile anlamlı bir ilişki bulunmadığı da görülmektedir.

Tablo 5'de ayrıca, otel yöneticilerinin (Ortalama; 14,03) göreve odaklı liderlik davranış biçimini, insana odaklı liderlik davranış biçiminden (Ortalama; 7,05) daha fazla tercih ettikleri de görülmektedir.

\subsection{Araştırma Hipotezlerinin Test Edilmesine İlişkin Bulgular}

Araştırma hipotezlerinin test edilmesi aşamasında, bağımsız değişkenin bağımlı değişken üzerindeki etkisinin belirlenmesine yönelik değerlendirme, çoklu doğrusal regresyon ile gerçekleştirilmiştir. Bu bağlamda, araştırma modelinden yola çıkarak, bağımsız değişken olan göreve ve insana odaklı liderlik boyutlarının bağımlı değişken olan çatışma çözme stratejileri üzerindeki etkisi, her bir çatışma çözme stratejisi alt boyutu için ayrı ayrı test edilmiştir.

Tablo 6: İnsana-Göreve Odaklı Liderlik Yaklaşımlarının Bütünleştirme Stratejisi Üzerindeki Etkisine İlişkin Regresyon Analizi Bulguları

\begin{tabular}{l|c|c|c|c|c}
\hline Değişken & $\mathrm{B}$ & $\mathrm{SH}$ & $\beta$ & $\mathrm{t}$ & $\mathrm{p}$ \\
\hline Sabit & 2,941 &, 245 & & 12,026 &, 000 \\
Göreve Odaklı L. &, 059 &, 020 &, 332 & 2,905 &, 005 \\
İnsana Odaklı L. &, 047 &, 027 &, 201 & 1,759 &, 082 \\
\hline
\end{tabular}

$\mathrm{R}=, 474, \mathrm{R}^{2}=, 225, \mathrm{~F}=12,466, \mathrm{p}=, 000$

Bağımlı Değişken: Bütünleştirme

Tablo 6 incelendiğinde göreve ve insana odaklı liderlik yaklaşımlarının birlikte oluşturduğu doğrusal kombinasyonun bütünleştirme stratejisi ile anlamlı bir ilişki sergilediği görülmektedir $\left(R=, 474 ; R^{2}=, 225\right.$; $\mathrm{p}<0,05)$. Göreve ve insana odaklı liderlik değişkenleri birlikte bütünleştirme stratejisi toplam varyansının $\% 22$ 'sini açıklamaktadır. Ayrıca standardize edilmiş $\beta$ katsayıları incelendiğinde yordayıcı değişkenlerin bütünleştirme üzerindeki göreli etki sıralamasında ilk sırada göreve odaklı liderlik yer almaktadır $(\beta=, 332)$. Regresyon katsayılarının anlamlılığ anlamlı bir yordayıcı olduğu görülmektedir $(\mathrm{p}<0,05)$. 


\section{D. Öztürk Çiftci - H. Erkanlı 12/4 (2020) 3930-3946}

Tablo 7: İnsana-Göreve Odaklı Liderlik Yaklaşımlarının Ödün Verme Stratejisi Üzerindeki Etkisine İlişkin Regresyon Analizi Bulguları

\begin{tabular}{l|c|c|c|c|c}
\hline Değişken & $\mathrm{B}$ & Sh & $\beta$ & $\mathrm{t}$ & $\mathrm{p}$ \\
\hline Sabit & 2,512 &, 235 & & 10,688 &, 000 \\
Göreve Odaklı L. &, 036 &, 019 &, 220 & 2,236 &, 064 \\
Insana Odaklı L. &, 057 &, 026 &, 263 & 1,759 &, 028 \\
\hline
\end{tabular}

$\mathrm{R}=, 426, \mathrm{R}^{2}=, 182, \mathrm{~F}=9,548, \mathrm{p}=, 000$

Bağımlı Değişken: Ödün Verme

Tablo 7 incelendiğinde göreve ve insana odaklı liderlik yaklaşımlarının birlikte oluşturduğu doğrusal kombinasyonun ödün verme stratejisi ile anlamlı bir ilişki sergilediği görülmektedir ( $\left.R=, 426 ; R^{2}=, 182 ; p<0,05\right)$. Göreve ve insana odaklı liderlik değişkenleri birlikte ödün verme stratejisi toplam varyansının \%18'sini açıklamaktadır. Ayrıca standardize edilmiş $\beta$ katsayıları incelendiğinde yordayıcı değişkenlerin ödün verme üzerindeki göreli etki sıralamasında ilk sırada insana odaklı liderlik yer almaktadır $(\beta=, 263)$. Regresyon katsayılarının anlamlılığı incelendiğinde ise, değişkenlerden yalnızca insana odaklı liderliğin anlamlı bir yordayıcı olduğu görülmektedir $(\mathrm{p}<0,05)$.

Tablo 8: İnsana-Göreve Odaklı Liderlik Yaklaşımlarının Hükmetme Stratejisi Üzerindeki Etkisine İlişkin Regresyon Analizi Bulguları

\begin{tabular}{l|c|c|c|c|c}
\hline Değişken & $\mathrm{B}$ & Sh & $\beta$ & $\mathrm{t}$ & $\mathrm{p}$ \\
\hline Sabit & 2,258 &, 318 & & 7,094 &, 000 \\
Göreve Odaklı L. &, 057 &, 026 &, 344 & 2,773 &, 007 \\
Insana Odaklı L. &,- 032 &, 035 &,- 113 &,- 914 &, 363 \\
\hline
\end{tabular}

$\mathrm{R}=, 296, \mathrm{R}^{2}=, 088, \mathrm{~F}=4,132, \mathrm{p}=, 019$

Bağımlı Değişken: Hükmetme

Tablo 8 incelendiğinde göreve ve insana odaklı liderlik yaklaşımlarının birlikte oluşturduğu doğrusal kombinasyonun hükmetme stratejisi ile anlamlı bir ilişki sergilediği görülmektedir $\left(R=, 296 ; R^{2}=, 088 ; p<0,05\right)$. Göreve ve insana odaklı liderlik değişkenleri birlikte, hükmetme stratejisi toplam varyansının \%9'unu açıklamaktadır. İnsana odaklı liderlik yaklaşımının hükmetme stratejisi üzerindeki etkisinin de negatif yönlü olduğu anlaşılmaktadır. Ayrıca standardize edilmiş $\beta$ katsayıları incelendiğinde yordayıcı değişkenlerin hükmetme üzerindeki göreli etki sıralamasında ilk sırada göreve odaklı liderlik yer almaktadır $(\beta=, 344)$. Regresyon katsayılarının anlamlılığı incelendiğinde ise, değişkenlerden yalnızca göreve odaklı liderliğin anlamlı bir yordayıcı olduğu görülmektedir $(p<0,05)$.

Tablo 9: İnsana-Göreve Odaklı Liderlik Yaklaşımlarının Kaçınma Stratejisi Üzerindeki Etkisine İlişkin Regresyon Analizi Bulguları

\begin{tabular}{l|c|c|c|c|c}
\hline Değişken & $\mathrm{B}$ & Sh & $\beta$ & $\mathrm{t}$ & $\mathrm{p}$ \\
\hline Sabit & 2,258 &, 318 & & 7,094 &, 000 \\
Göreve Odaklı L. &, 057 &, 026 &, 344 & 2,773 &, 007 \\
İnsana Odaklı L. &,- 032 &, 035 &,- 113 &,- 914 &, 363 \\
\hline
\end{tabular}

$\mathrm{R}=, 187, \mathrm{R}^{2}=, 035, \mathrm{~F}=1,564, \mathrm{p}=, 215$

Bağımlı Değişken: Kaçınma

Tablo 9 incelendiğinde, göreve ve insana odaklı liderlik yaklaşımlarının birlikte oluşturduğu doğrusal kombinasyon ile kaçınma stratejisi arasında anlamlı bir ilişki olmadı̆̆ görülmektedir ( $>>0,05$ ). Ayrıca, regresyon katsayılarının anlamlılık değerleri de gerek göreve odaklı gerekse insana odaklı liderlik değişkenlerinin kaçınma stratejisi üzerinde anlamlı bir etkisinin olmadığını göstermektedir $(p>0,05)$. 
Tablo 10: İnsana-Göreve Odaklı Liderlik Yaklaşımlarının Uzlaşma Stratejisi Üzerindeki Etkisine İlişkin Regresyon Analizi Bulguları

\begin{tabular}{l|c|c|c|c|c}
\hline Değişken & $\mathrm{B}$ & $\mathrm{Sh}$ & $\beta$ & $\mathrm{t}$ & $\mathrm{p}$ \\
\hline Sabit & 2,828 &, 269 & & 10,495 &, 000 \\
Göreve Odaklı L. &, 064 &, 022 &, 342 & 2,864 &, 005 \\
İnsana Odaklı L. &, 019 &, 029 &, 077 &, 642 &, 522 \\
\hline
\end{tabular}

$\mathrm{R}=, 390, \mathrm{R}^{2}=, 152, \mathrm{~F}=7,720, \mathrm{p}=, 001$

Bağımlı Değişken: Uzlaşma

Tablo 10 incelendiğinde göreve ve insana odaklı liderlik yaklaşımlarının birlikte oluşturduğu doğrusal kombinasyonun uzlaşma stratejisi ile anlamlı bir ilişki sergilediği görülmektedir $\left(R=, 390 ; R^{2}=, 152 ; p<0,05\right)$. Göreve ve insana odaklı liderlik değişkenleri birlikte, uzlaşma stratejisi toplam varyansının \%15'ini açıklamaktadır. Ayrıca standardize edilmiş $\beta$ katsayıları incelendiğinde yordayıcı değişkenlerin hükmetme üzerindeki göreli etki sıralamasında ilk sırada göreve odaklı liderlik yer almaktadır $(\beta=, 344)$. Regresyon katsayılarının anlamlılığı incelendiğinde ise, değişkenlerden yalnızca göreve odaklı liderliğin anlamlı bir yordayııı olduğu görülmektedir $(\mathrm{p}<0,05)$.

\section{SONUÇ VE TARTIŞMA}

$\mathrm{Bu}$ araştırma, otel yöneticilerinin liderlik yönelimlerinin çatışma çözme konusundaki stratejileri üzerinde anlamlı bir etkisinin olup olmadığının belirlenmesi amacıyla gerçekleştirilmiştir. Bu amaçla Orta ve Doğu Karadeniz Bölgesi'nde yer alan 4 ve 5 yıldızlı otellerde yönetici pozisyonunda çalışanlar örneklem çerçevesi olarak belirlenmiştir. Kavramsal çerçeve temelinde hipotezler oluşturulmuş ve söz konusu hipotezler istatistiksel analiz yöntemleri ile test edilmiştir. Yapılan değerlendirmeler neticesinde, bu araştırmada göreve ve insana odaklı liderlik şeklinde ele alınan lider davranış biçimlerinin, çatışma çözme yöntemlerinden bütünleştirme, ödün verme, kaçınma ve uzlaşma stratejileri üzerinde anlamlı bir etkisinin olduğu ancak hükmetme stratejisi üzerinde ise anlamlı bir etkisinin olmadığı tespit edilmiştir. Yine araştırma bulguları söz konusu etkilerin göreli sıralamasında bütünleştirme, hükmetme ve uzlaşma stratejilerinin seçiminde göreve odaklı liderlik davranışının; ödün verme stratejisinin seçiminde ise insana odaklı davranış biçiminin ilk sırada yer aldığını göstermektedir. Bir başka ifadeyle, bütünleştirme, hükmetme ve uzlaşma stratejilerini seçen liderlerin göreve ve insana odaklı eğilimlerinin doğrusal bütünleşik etkisinde göreve odaklı davranış eğilimi ağır basarken, ödün verme stratejisini seçen liderlerin göreve ve insana odaklı eğilimlerinin doğrusal bütünleşik etkisinde insana odaklı davranış biçimi ağır basmaktadır.

Yazında çatışma yönetim stratejilerini farklı liderlik yönelimleri açısından inceleyen araştırmalar da lider davranış biçimlerinin çatışmayı çözme konusundaki stratejiler üzerinde etkisi olduğunu doğrulamaktadır. Erzen ve Armağan (2015), liderliğin çatışma çözme üzerindeki etkisini konu edinen araştırmaları meta analiz yöntemi ile değerlendirmişlerdir. Yazarlar çalışmalarının sonunda, liderliğin çatışma çözümü üzerindeki etkisini doğrulamakta ve farklı lider yaklaşımlarının çatışma sürecinin farklı şekillenmesine ve sonuçlanmasına neden olabileceğini ifade etmişlerdir. Benzer şekilde Hendel vd., (2005); Tanrıverdi vd., (2016); Nalbantoğlu ve Akıncı (2019); Korkmaz ve Çağlı (2019); Khan vd (2015) de farklı liderlik yaklaşımları ile gerçekleştirdikleri araştırmalarda, liderlik tarzları ile çatışma çözme yöntemleri arasında anlamlı ilişkiler saptamışlardır.

Araştırma bulguları, yöneticilerin göreve ve insana odaklı liderlik yaklaşımlarının çatışma çözüm stratejilerinden bütünleştirme üzerinde anlamlı bir etkisi olduğunu göstermektedir (H1 Kabul edilmiştir). Çoklu doğrusal regresyon analizi bulguları ayrıca bu etkinin göreli sırasında ilk sırada göreve odaklı liderliğin yer aldığına da işaret etmektedir. Bu durum, göreve odaklı liderlerin, örgüt içinde çalışanlara birçok konuda rehberlik ettiği ve gelişmiş bir organizasyon yetenekleri olduğu düşünüldüğünde, özellikle iletişim eksikliğinden kaynaklanan sorunların çözümünde uygulanması önerilen ve tarafların bir araya getirilmesi temeline dayanan bütünleştirme stratejisini uygulamaları ile açıklanabilir. İnsana odaklı liderlerin açısından değerlendirildiğinde de bu tarz liderlerin, çalışanlar ile oluşturduğu karşılıklı güvene dayalı ilişkiler sayesinde tarafları bir araya getirebilme gücüne sahip oldukları, bu nedenle bütünleştirme stratejisine yönelebildikleri söylenebilir. Bolat (2018), araştırma bulgularını destekler şekilde, tekstil sektörü çalışanları ile gerçekleştirdiği araştırmada, göreve ve insana odaklı liderlik yaklaşımları ile çatışma çözmede bütünleştirme stratejisi arasında pozitif yönlü ve güçlü bir ilişki olduğunu tespit etmiştir. Ayrıca, Korkmaz ve Yalçın'ın (2015), sağlık 


\section{D. Öztürk Çiftci - H. Erkanlı 12/4 (2020) 3930-3946}

sektöründe gerçekleştirdikleri araştırmada, çatışma çözme stratejileri ile hem astları ile bireysel olarak ilgilenen ve onların problemlerine çözüm bulmaya çalışan liderlik davranış biçimleri; hem de amaçların gerçekleştirilmesini ön planda tutan liderlik tarzları arasında pozitif yönlü bir ilişki olduğu yönündeki sonuçları araştırma bulgularını desteklemektedir. Kamer (2018), yine sağlık sektöründe yapmış olduğu araştırmada, liderin destekleyici davranış biçimi ile Tüfekçi ve Haque (2019) ise bireysel ilgi gösterme davranış biçimi ile bütünleştirme stratejisi arasında pozitif yönlü bir ilişki tespit etmiştir. İnsana odaklı liderlerin belirgin özelliklerinden birinin de çalışanlara ilgi gösteren, destekleyici yaklaşımları olduğu göz önünde bulundurulduğunda, söz konusu sonuçların araştırma bulgularını desteklediği ifade edilebilir.

Bulgular, göreve ve insana odaklı liderlik yaklaşımlarının birlikte, çatışma çözme stratejilerinden ödün verme üzerinde etkili olduklarını göstermektedir (H2 Kabul edilmiştir). Ancak, bu etkide göreli öneme sahip olan liderlik yaklaşımının insana odaklı liderlik yaklaşımı olduğu görülmektedir. Ödün verme stratejisi, çatışmanın çözüme ulaştırılması amacıyla taraflardan birinin taviz vermesi ve diğer tarafın beklentilerinin karşılanmasına göz yumması temelinde gerçekleşmektedir. Bu bağlamda bu stratejinin uygulanması noktasında, çalışanları ile yakın ilişkiler geliştirmeyi başaran insan odaklı liderlerin, görevlerin yerine getirilmesini her şeyin üzerinde tutan görev odaklı liderlerden daha etkin olması beklenebilir. Bir başka ifadeyle bulgular, çalışanlar ile arasında yüksek düzeyde güven geliştirebilen insan odaklı liderlerin, çatışma taraflarını ödün verme konusunda ikna edebileceğini düşünmeye daha yatkın olması ile açılanabilir. Söz konusu bulgulara benzer biçimde Odabaşıŏ̆lu (2013), yaptığı araştırmada göreve ve insana odaklı liderliğin ödün verme stratejisi üzerindeki etkisinin anlamlı olduğu ancak insana odaklı liderliğin göreli öneminin daha büyük olduğu sonucuna ulaşmıştır. Khan vd (2015), banka sektöründe gerçekleştirdikleri araştırmada, ödün verme stratejisi ile insana odaklı liderlik arasında pozitif yönlü, göreve odaklı liderlik arasında ise negatif yönlü bir ilişkinin var olduğuna işaret eden bulgular elde etmişlerdir. Bolat (2018) ise araştırmasında hem insana hem de göreve odaklı liderlik yaklaşımlarının, ödün verme stratejisi üzerinde pozitif yönlü etkisi olduğunu ortaya koymuştur.

Araştırmada, göreve ve insana odaklı liderlik yaklaşımlarının birlikte, çatışma çözme stratejilerinden hükmetme üzerinde etkili olduklarını gösteren bulgular elde edilmiştir (H3 Kabul edilmiştir). Ancak, bu etkide göreli öneme sahip olan liderlik yaklaşımının göreve odaklı liderlik yaklaşımı olduğu görülmektedir. Göreve odaklı liderlerin yüksek performansa ulaşmak amacıyla, çalışanları yönlendirmeye ve gücü elinde bulundurmaya olan yatkınlıkları ile çalışanların içinde bulundukları durumu ikinci planda tutan yaklaşımlarının çatışmanın baskı yoluyla çözümüne karşılık gelen hükmetme stratejisini uygulamaya eğilimli olmalarını açıkladığı söylenebilir. Araştırma sonuçları ile aynı doğrultuda, Man Chu (2011), kendini çalışanlarına adama yönü ile insana odaklı liderlik ile örtüşen hizmetkâr liderlik tarzının çatışma yönetme stratejileri ile olan ilişkilerini incelediği araştırmasında, hükmetme stratejisi ile hizmetkar liderlik arasında anlamlı bir ilişkinin olmadığını doğrulayan bulgulara ulaşmıştır. Madlock (2013) ise hem insana hem de göreve odaklı liderlik ile hükmetme stratejisi arasında negatif yönlü ve istatistiksel olarak anlamlı bir ilişkinin olduğunu tespit etmiştir.

Araştırmada elde edilen bulgular, göreve ve insana odaklı liderlik yaklaşımlarının birlikte, çatışma çözme stratejilerinden kaçınma üzerinde anlamlı bir etkisinin olmadığını göstermektedir (H4 reddedilmiştir). Araştırma sonuçları ile uyumlu olarak Sayeed ve Mathur (1980) ile Pour vd., (2012), farklı sektörlerden oluşan örneklem dahilinde gerçekleştirdikleri araştırmalarda, liderin göreve veya insana odaklı davranış biçimi ile çatışma yönetiminde kaçınma stratejisi arasında anlamlı bir ilişkinin olmadığı sonucuna ulaşmışlardır. Benzer şekilde Odabaşıŏ̆lu (2013) da eğitim sektöründe gerçekleştirdiği araştırmada, göreve ve insana odaklı liderlik yaklaşımlarının kaçınma stratejisi ile düşük düzeyde ilişkili olduğu sonucuna ulaşmıştır.

Araştırmada göreve ve insana odaklı liderlik yaklaşımlarının birlikte, çatışma çözme stratejilerinden uzlaşma üzerinde etkili olduklarını göstermektedir (H5 Kabul edilmiştir). Ancak, bu etkide göreli öneme sahip olan liderlik yaklaşımının göreve odaklı liderlik yaklaşımı olduğu görülmektedir. Elde edilen bulgular, iki liderlik davranış biçiminin bütüncül etkisi bakımından yazındaki araştırmalar ile genel anlamda örtüşmekle birlikte, davranış biçimleri nedeniyle uzlaşmacı eğilime sahip olan insana odaklı liderlik yaklaşımının etkisinin anlamlı olmayışı açısından yazından farklılaşmaktadır. Örneğin, Madlock (2013); Odabaşığlu (2013) yaptıkları araştırmalarda hem insana hem de göreve odaklı liderlik ile uzlaşmacı strateji arasında pozitif yönlü ve anlamlı bir ilişkininin varlığını doğrulayan sonuçlara ulaşmışlardır. Ayrıca her iki araştırmada da, uzlaşma 


\section{D. Öztürk Çiftci - H. Erkanlı 12/4 (2020) 3930-3946}

stratejisinin insana odaklı liderlik ile arasındaki ilişkinin, göreve odaklı liderlik ile arasındaki ilişkiden daha güçlü olduğu tespit edilmiştir.

Araştırma sonuçları, özellikle çalışanların müşteri ile doğrudan iletişim halinde olduğu otel işletmeleri yöneticilerinin göreve ya da insana odaklı liderlik davranış biçimlerinin çatışma çözümündeki etkisini ortaya koymaktadır. Özellikle turizm sektörü gibi müşterilerin bire bir işletme içinde yer aldığı sektörlerde, çalışanların içinde bulunduğu çatışma süreçlerinin çözüme kavuşturulmamasının olumsuz etkileri doğrudan hissedilmektedir. Uzun süren çatışmaların gerek örgütsel gerekse bireysel olarak yıkıcı etkilerinin önlenmesi, hatta çatışmanın olumlu yönlerinin fırsata dönüştürülmesi ise, yaşanan çatışmanın ortaya çıkış şekline ve özelliklerine göre doğru strateji ile yönetilmesine bağlıdır. Sonuç olarak, bu araştırma insana ve göreve odaklı liderlik biçimlerinin karakteristik özelliklerinin örgütlerde çatısmanın çözümü konusunda izlenecek strateji seçiminde belirleyici bir unsur olduğunu doğrulamaktadır. Dolayısıyla çatışmanın olumsuz etkilerini en az düzeye indirgeyecek ve örgütsel yapıya uygun çözüm için doğru stratejilerin belirlenmesinde liderin insanı ya da görevi önceleyen tutumu etkili olmaktadır.

Araştırma sonuçları, örneklem büyüklüğü, katılımcıların kişisel özelliklerine bağlı algılama biçimleri gibi sınırlılıkları çerçevesinde değerlendirilmelidir. Araştırmanın farklı örneklemlerde tekrarlanmasının, sonuçların genel düzeyde değerlendirilmesine katkı sağlayacağı düşünülmektedir. Ayrıca araştırma kesitsel nitelik taşımaktadır. Bu nedenle değişkenler arası ilişkilerin boylamsal araştırmalar ile sınanması önerilebilir. Ayrıca, araştırma örnekleminin (araştırma evreninin büyüklüğüne bağlı olarak ve temsil edilmesi bakımından yeterli olmakla birlikte) küçük oluşu, araştırma sonuçları bakımından göz önünde bulundurulması gereken diğer bir kısıttır.

\section{Kaynakça}

Arslan, K. (2016). KOBI'lerde Çatışma ve KOBİ yöneticilerinin çatışmanın yönetiminde izledikleri stratejiler, Kocaeli Üniversitesi Sosyal Bilimler Dergisi, 32, 35-62.

Ayan, B. ve Yavuz, E. (2018). Örgütsel çatışma ve yönetim: Kamu örgütlerinde bir araştırma, İşletme Araştırmaları Dergisi, 10(1), 745-762.

Aydın, Ş. (2004). Otel işletmelerinde örgütsel stres faktörleri: 4-5 yıldızlı otel işletmeleri uygulaması, Dokuz Eylül Üniversitesi Sosyal Bilimler Enstitüsü Dergisi, 6(4), 1-21.

Bolat, G. (2018). Algılanan liderlik davranışının örgütsel çatışma yönetim stili ve tükenmişlik üzerine etkisi, Yayımlanmamış Yüksek Lisans Tezi, Hasan Kalyoncu Üniversitesi Sosyal Bilimler Enstitüsü, Gaziantep.

Bumin, B. (1990). İşletmelerde Organizasyon Geliştirme ve Çatışmanın Yönetimi, Gazi Üniversitesi İ̈BF: Ankara.

Can, A. (2017). SPSS ile Bilimsel Araştırma Sürecinde Nicel Veri Analizi, Pegem Akademi, Ankara.

Casimir, G. ve Ngee Keith Ng, Y. (2010). Combinative aspects of leadership style and the interaction between leadership behaviors, Leadership \& Organization Development Journal, 31 (6), 501-517.

Chandolia, E., ve Anastasiou, S. (2020). Leadership and conflict management style are associated with the effectiveness of school conflict management in the Region of Epirus, NW Greece, European Journal of Investigation in Health, Psychology and Education, 10(1), 455-468.

Chen, H.X, Xu, X. ve Phillips, P. (2019). Emotional intelligence and conflict management styles. International Journal of Organizational Analysis, 27(3), 458-470

Cömert, S. (1999). Yöneticilerin yaratıcılık düzeyleri ile liderlik tarzları arasındaki ilişki, İstanbul Üniversitesi Sosyal Bilimler Enstitüsü İşletme Fakültesi Doktora Tezi, İstanbul

Donnelly, J.H., Gibson, J.L. and Ivancevich, J.M. (1998). Fundementals of Management, 10th. Ed. California: McGraw Hill Co., USA.

Eren, E. (2011). Yönetim ve Organizasyon: Çağdaş ve Küresel Yaklaşımlar, İstanbul: Beta Yayınları.

Erol, E., ve Koç, H. (2017). Konaklama işletmeleri yöneticilerinin liderlik davranışlarının belirlenmesine yönelik bir uygulama. Journal of Tourism and Gastronomy Studies, 5(4), 566-580. 
Erzen, E. ve Armağan, Y. (2015). The effect of leadership on conflict management, E. Karadağ (ed.). Leadership and Organizational Outcomes Meta-Analysis of Empirical Studies (225-237 ss), Springer International

Francis, G. ve Milbourn J.G. (1980). Human Behaviour in the Work Environment: A Managerial Perspective, Goodyear Publishing Company Inc, California. Publishing, Switzerland.

Gündüz Çekmecelioğlu, H. (2014). Göreve ve insana yönelik liderlik tarzlarının örgütsel bağlllık, iş performansı ve işten ayrılma niyeti üzerindeki etkileri, Kocaeli Üniversitesi Sosyal Bilimler Dergisi, 28, 21-34.

Gürer, A., Öneren, M. ve Bozacı, İ. (2014). Çalışanların bireysel değerleri ile örgütsel çatışma yönetimi arasındaki ilişkinin belirlenmesi: Kamu yöneticileri üzerine bir araştırma", International Journal of Social Science, 29, 439-455.

Hendel, T., Fish, M. ve Galon, V. (2005). Leadership style and choice of strategy in conflict management among Israeli nurse managers in general hospitals, Journal of Nursing Management, 13, 137-146.

Hu, Sunny', Cheng, C.-W., (2010). Job stress, coping strategies, and burnout among hotel industry supervisors in Taiwan, International Journal of Human Resource Management, 21, 1337-1350.

Jokanović, B., Tomić, I. ve Duđak, L. (2017). Organizational conflict resolution, XVII International Scientific Conference on Industrial Systems (IS'17), Serbia.

Kamer, H. (2018). Hastane yöneticilerinin liderlik tarzlarının çatışma yönetim stratejilerine etkisi, Yayımlanmamış Doktora Tezi, Marmara Üniversitesi Sağlık Bilimleri Enstitüsü, İstanbul.

Khan, M., Langove, N., Shah, F.A. ve Javid, M.U. (2015). The modes of conflicts and managerial leadership styles of managers, Global Business and Management Research: An International Journal, 7(2), 44-52.

Khuong, M.N. ve Hoang, D.T. (2015). The effects of leadership styles on employee motivation in auditing companies in Ho Chi Minh City, Vietnam, International Journal of Trade, Economics and Finance, 6(4), 210-217.

Kocaman, S., Kocaman, S. ve Çakır, N. (2012). Konaklama işletmelerinde örgüt kültürünün örgütsel çatışma üzerine etkileri: Alanya bölgesinde bir araştırma, Mŭ̆la Üniversitesi Sosyal Bilimler Enstitüsü Dergisi, $28,167-183$.

Koçak, S., ve Atanur Başkan, G. (2013). Okul müdürleri tarafından kullanılan çatışma yönetim yöntemlerinin etkililik düzeyleri. Hacettepe Üniversitesi Eğitim Fakültesi Dergisi, 44(44), 212-224.

Koçel, T. (2014). İşletme Yöneticiliği, Beta Yayınları: İstanbul.

Korkmaz, Z. ve Yalçın, B. (2015). Liderlik tarzları ve çatışma yönetimi stratejileri ilişkisine yönelik bir alan araştırması: Sağlık yöneticileri örneği, Dayanışma, 41-51.

Korkmaz, M. ve Çağlı, M. (2019). Eğitim yöneticilerinin liderlik tarzları ile çatışma yönetim stratejileri arasındaki ilişkinin incelenmesi, TURAN-SAM Uluslararası Bilimsel Hakemli Dergisi, 11(4), 77-90.

Leonard, K. (2020). Advantages \& Disadvantages of People-Oriented Leadership Styles, https://smallbusiness.chron.com/advantages-disadvantages-peopleoriented-leadership-styles 10299.html (03.05.2020 tarihinde erişildi).

Limbare, S. (2012). Leadership styles \& conflict management styles of executives, The Indian Journal of Industrial Relations, 48(1), 172-180.

Luthans, F. (1992). Organizational Behavior. 4. Bask1. New Jersey, NJ: McGraw-Hill, Inc.

Madalina, O. (2016). Conflict management, a new challenge. Procedia Economics and Finance, 39, 807-814.

Madlock, P. E. (2013). The influence of conflict management, leadership, and communication on employee job satisfaction. Human Communication, 15, 121-138.

Man Chu, R.I. (2011). Conflict management styles of pastors and organizational servant leadership: A descriptive study". Journal of Applied Christian Leadership, 5(2), 117-117. 
Mathieu, C., Fabi, B., Lacoursière, R., ve Raymond, L. (2016). The role of supervisory behavior, job satisfaction and organizational commitment on employee turnover. Journal of Management \& Organization, 22(01), $113-129$.

Nalbantoğlu, C.B. ve Akıncı, G. (2019). Türk - İsveç iş kültüründe liderlik tarzlarının çatışma çözüm yönetimi üzerine etkisi", Balkan ve Yakın Doğu Sosyal Bilimler Dergisi, 5(4), 68-84.

Odabaşıoğlu, F. (2013). İlkokul ve ortaokul müdürlerinin liderlik davranışları ve çatışma yönetimi stillerine ilişkin öğretmen algıları", Yayımlanmamış Yüksek Lisans Tezi, Maltepe Üniversitesi Sosyal Bilimler Enstitüsü: İstanbul.

Özdevecioğlu, M. ve Kanıgür, S. (2009). Çalışanların ilişki ve görev yönelimli liderlik algılamalarının performansları üzerindeki etkileri. Karamanoğlu Mehmetbey Üniversitesi Sosyal ve Ekonomik Araştırmalar Dergisi, (1), 53-82.

Pour, S.M., Zadeh, A.B ve Barati, E. (2012). An empirical study to measure the relationship between management style and conflict management, Management Science Letters, 2, 2249-2254.

Rahim, M. A. (1983). A measure of styles of handling interpersonal conflict. Academy of Management Journal, $26,368-376$.

Rahim, M.A., Buntzman, G.F. ve White, D. (1999). An empirical study of the stages of moral development and conflict management styles, The International Journal of Conflict Management, 10(2), 154-171.

Rahim, M.A. (2002). Toward a theory of managing organizational conflict, The International Journal of Conflict Management, 13(3), 206-235.

Rahim, M.A. ve Katz, J. (2020). Forty years of conflict: the effects of gender and generation on conflictmanagement strategies, International Journal of Conflict Management, 31(1), 1-16.

Ribiere, M.V. ve Sitar, S.A. (2003). Critical role of leadership in nurturing a knowledge-supporting culture, Knowledge Management Research \& Practice, 1, 39-48.

Richmond, V. P., Wagner, J. P., ve McCroskey, J. C. (1983). The impact of perceptions of leadership style, use of power, and conflict management style on organizational outcomes, Communication Quarterly, 31(1), $27-36$.

Robbins, S.P. ve Judge, T.A. (2017). Örgütsel Davranış, (İnci Erdem, Çev.Ed.). Ankara: Nobel Yayınları.

Rüzgar, N. (2018). The effect of leaders' adoption of task-oriented or relationship-oriented leadership style on leader-member exchange (LMX), In the organizations that are active in service sector: A research on tourism agencies, Journal of Business Administration Research, 7(1), 50-60.

Saeed, T., Almas, S., Anis-ul-Haq, M., ve Niazi, G. S. K. (2014). Leadership styles: Relationship with conflict management styles. International Journal of Conflict Management, 25(3), 214-225.

Sayeed, O.B. ve Mathur, H.B. (1980). Leadership behaviour and conflict management strategies, Vikalpa, 5(4), 275-282.

Sportsman, S. ve Hamilton, P. (2007). Conflict management styles in the health professions, Journal of Professional Nursing, 23 (3), 157-166.

Standling, J. (2014). Little Miss Task Oriented. https://jonathansandling.com/task-oriented-leadership/ (09/05/2020 tarihinde erişildi).

Tabachnick, B. G., ve Fidell, L. S. (2013). Using multivariate statistics (Sixth edition). United States: Pearson Education.

Tanrıverdi, H., Akova, O. ve Çifçi, İ. (2018). Aç1lış-otellerinde dönüşümcü, etkileyici, tam serbesti tanıyan liderlik tarzlarının ve çatışma yönetim stillerinin işten ayrılma niyeti üzerine etkisi", KMÜ Sosyal ve Ekonomik Araştırmalar Dergisi, 18 (30), 114 - 123.

Taşkıran, E. (2006). Otel işletmelerinde çalışan yöneticilerin liderlik yönelimleri: İstanbul'daki beş yıldızlı otel işletmelerinde bir araştırma", Anatolia: Turizm Araştırmaları Dergisi, 17(2), 169-183. 
D. Öztürk Çiftci - H. Erkanlı 12/4 (2020) 3930-3946

Tengilimoğlu, D., Atilla, E.A. ve Bektaş, M. (2014). İşletme Yönetimi. Seçkin Yayınları: Ankara.

Tiyce, M., Hing, N.Cairncross, G. ve Breen, H.(2013), Employee stress and stressors in gambling and hospitality workplaces", Journal of Human Resources in Hospitality \& Tourism, 12(2),126-154.

Topaloğlu, C. ve Boylu, Y. (2006). Örgüt içi çatışmaların türleri: Otel işletmeleri açısından ayrıntılı bir inceleme, Mŭ̆la Üniversitesi Sosyal Bilimler Enstitüsü Dergisi, 16.

Tuna, M. ve Türkmen, F. (2015). Kişilik tiplerinin çatışmayı yönetme yöntemlerine etkisi, İşletme Araştırmaları Dergisi, 7(4), 43-65.

Turkalj, Z., Fosiz, I. Ve Dujak, D. (2008). Conflict management in organization, Interdisciplinary Management Research IV, 505-515.

Tüfekçi, N. ve Haque, H.S. (2019). Yöneticilerin örgütsel çatışma yönetiminde modern liderlik tarzlarının rolü: Karşılaştırmalı bir araştırma", Journal of Current Researches on Health Sector, 9 (1), 9-24.

Üngüren, E. (2009). Çalışma hayatında örgütsel çatışma: Konaklama işletmeleri üzerinde bir araştırma, Çalışma ve Toplum, 1, 95-127.

Waqar, H.S. ve Siddiqui, K. (2008). A study about the leadership styles of public and private school principals, Journal of Elementary Education, 18(1-2), 5-20.

Wilkinson, R. (2018). Leadership and Management: Connecting the Dots, Xlibris Publishing, Indiana:USA.

Yağcıŏ̆lu, B. D. (1997). Örgütlerde çatışma düzeyleri ve çatışmanın ele alınış stilleri. Yüksek lisans tezi, Ege Üniversitesi Sosyal Bilimler Enstitüsü, İzmir.

Yukl, G. (1971). Toward a behavioral theory of leadership", Organizational Behavior and Human Performance, 6(4), 414-440.

Yukl, G., Gordon, A. ve Taber, T. (2002). A hierarchical taxonomy of leadership behavior: Integrating a half century of behavior research". Journal of Leadership and Organizational Studies, 9(1), 15-32.

Yukl, G. (2006). Leadership in organizations (6th ed.). Upper Saddle River, NJ: Pearson-Prentice Hall. 